\title{
PENDAMPINGAN UPPKS MEKAR INDAH DI DESA TANAH MERAH KABUPATEN SERDANG BEDAGAI MELALUI PENGEMBANGAN DESAIN PEMASARAN
}

\author{
Dita Amanah ${ }^{1 *}$, Kustoro Budiarta ${ }^{1}$ \\ ${ }^{1}$ Jurusan Manajemen, Fakultas Ekonomi, Universitas Negeri Medan, Medan \\ *Penulis Korespodensi : ditamnh@yahoo.com
}

\begin{abstract}
Abstrak
Secara umum kegiatan ini bertujuan untuk perbaikan pada pengembangan desain pemasaran. Secara khusus tujuan pendampingan UPPKS Mekar Indah, yaitu: 1) Desain produk olahan, 3) Pemberian alat pengemasan produk (bag sealer), 4) Perbaikan pada manajemen usaha: catatan pembukuan, perencanaan dan penyusunan laporan keuangan serta penyusunan proposal kredit. Model pelaksanaan kegiatan adalah dengan memberikan pelatihan atau workshop manajemen usaha, pelatihan pembukuan sederhana dan pendampingan dalam mengembangkan desain pemasaran serta simulasi penggunaan alat pengemasan produk. Hasil yang diperoleh dari kegiatannya ini antara lain: 1) Kelompok UPPKS Mekar Indah memiliki pengemasan produk yang baru dan memiliki alat pengemasan, 2) Perbaikan Manajemen Usaha seperti pembukuan dan laporan keuangan secara sederhana serta penyusunan rancangan bisnis. Berdasarkan evaluasi dari kegiatan pendampingan terhadap UPPKS Mekar Indah, maka rekomendasi yang perlu disampaikan adalah keberlanjutan pendampingan UPPKS Mekar Indah yang selalu diberikan BKKBN dan perlu pendampingan inovasi produk lebih lanjut serta sistem perluasan pangsa pasar.
\end{abstract}

Kata kunci : Pendampingan, Desain Pemasaran dan Manajemen Usaha

\begin{abstract}
In general, this activity aims to improve on the development of marketing design. In particular the purpose of assistance to UPPKS Mekar Indah, namely: 1) Design of products, 3) Provision of bag sealer, 4) Improvements in business management: accounting records, planning and preparation of financial statements and preparation of credit proposals. The implementation model of the activities is to provide training or business management workshops, simple bookkeeping training and mentoring in developing the marketing design and simulating the use of product packaging tools. The results obtained from these activities include: 1) UPPKS Mekar Indah Group has new product packaging and has packaging equipment, 2) Business Management Improvements such as simple bookkeeping and financial reporting as well as business plan drafting. Based on the evaluation of the mentoring activities to UPPKS Mekar Indah, the recommendation that needs to be submitted is the continuity of UPPKS Mekar Indah assistance which always provided by BKKBN and need to assist in further product innovation and market expansion system.
\end{abstract}

Keywords : Assistance, Marketing Design and Business Management

\section{PENDAhuluan}

Permendagri RI Nomor 7 Tahun 2007 tentang

Kader Pemberdayaan Masyarakat, menyebutkan bahwa "Pemberdayaan masyarakat adalah suatu strategi yang digunakan dalam pembangunan masyarakat sebagai upaya untuk mewujudkan kemampuan dan kemandirian dalam kehidupan bermasyarakat, berbangsa dan bernegara." Konsep pemberdayaan masyarakat dapat dimaknai dalam konteks menempatkan posisi berdiri masyarakat. Bentuk implementasi pemberdayaan masyarakat adalah Usaha Peningkatan Pendapatan Keluarga (UP2K). UP2K merupakan salah satu implementasi kebijakan bidang pemberdayaan wanita dari segi perekonomian yang paling relevan dalam membantu pemerintah untuk membangun masyarakat yang mandiri. Masyarakat yang mandiri sebagai partisipan, membuka ruang dan kapasitas mengembangkan potensi-kreasi, mengontrol lingkungan dan sumber dayanya sendiri, menyelesaikan masalah secara mandiri, dan ikut berpartisipasi dalam proses pembangunan. Untuk itu masyarakat perlu diberikan pengetahuan, pemahaman, dan keterampilan mengenai pembangunan jiwa kewirausahaan dalam rangka membentuk sikap mental yang mandiri, pantang menyerah, kreatif serta mengembangkan need for achievement, sehingga potensi yang dimiliki maupun fasilitas yang diperoleh dapat dikembangkan. 
Tujuan umum dari UP2K ini adalah membina dan mengembangkan kegiatan usaha keluarga yang tergabung dalam kelompok atau perorangan sehingga secara bertahap mampu menjadi wirausaha. Sementara sasaran kegiatan UP2K adalah keluargakeluarga yang berpenghasilan rendah dan telah memiliki kegiatan usaha yang tergabung dalam kelompok dan benar-benar membutuhkan penambahan dana usaha serta memungkinkan timbulnya kegiatan yang bersifat koperatif.

Kabupaten Serdang Bedagai merupakan salah kabupaten di Provinsi Sumatera Utara yang mendapat dana bergulir UP2K. Salah satu kelompok yang memperoleh dana bergulir UP2K di Kabupaten Serdang Bedagai adalah Kelompok Mekar Indah yang berada di Desa Tanah Merah di Kecamatan Perbaungan yang merupakan salah satu kecamatan miskin yang ada di Kabupaten Serdang Bedagai. Dasar dari pemberian bantuan adalah melihat kepada besarnya tingkat kemiskinan dan pertimbangan lainnya seperti dari segi perkembangan serta peran aktifnya kelompok PKK di desa. Dengan bantuan ini diharapkan terjadi peningkatan pendapatan kaum perempuan, kesempatan berusaha sehingga pada akhirnya mampu meningkatkan kesejahteraan keluarga. Dana bantuan tersebut digunakan untuk pengembangan usaha kecil yang dilakukan kelompok UP2K. Adapun jenis usaha yang dikembangkan oleh kelompok Mekar Indah adalah usaha berbagai olahan kripik dengan bahan baku pisang dan singkong. Kelompok ini diketuai oleh Ibu Nuraini dengan jumlah anggota kelompok sebanyak 10 orang. Jumlah dana yang diperoleh saat ini sebesar Rp 2.500.000,00 atau sebesar $\mathrm{Rp} 250.000,00$ per orang.

Beberapa permasalahan yang terungkap dari hasil obervasi pada Kelompok usaha Mekar Indah antara lain :

1. Sebagian masyarakat yang penghidupannya dari bertani atau menjadi buruh, sehingga usaha lebih banyak diusahakan untuk memenuhi kebutuhan keluarga, belum banyak diorientasikan untuk bisnis.

2. Tingkat pendidikan dan pengetahuan masyarakat sangat rendah sehingga kreativitas dan inovasi masyarakat terutama masyarakat usia produktif yang mau berusaha membangun usaha kecil sangat rendah.

3. Dari 10 pelaku usaha kecil pada Kelompok Mekar Indah, seluruhnya telah mengisi angket untuk mengetahui kondisi masing-masing usaha. Dari hasil pengumpulan data melalui angket tersebut, diketahui permasalahan yang dihadapi adalah :

a. Faktor Modal/Keuangan

Dukungan modal usaha sangat kurang, seluruh anggota hanya menerima bantuan modal masing-masing sebesar Rp 250.000,00 sehingga modal yang digunakan untuk usaha lebih banyak berasal dari modal sendiri.

b. Faktor Pengembangan Usaha
1) Usaha dilakukan tidak melalui perencanaan

2) Tidak dilakukan pencatatan keuangan

3) Desain kemasan tidak baik untuk produk yang dihasilkan

4) Kurangnya jalur distribusi pemasaran

c. Faktor SDM

1) Rendahnya pengetahuan dan keterampilan untuk meningkatkan daya saing usaha.

2) Rendahnya kemampuan komunikasi yang dibutuhkan dalam rangka menunjang pengembangan usaha.

Salah satu produk olahan Kelompok Mekar Indah ialah kripik ubi balado yang mampu terjual hingga mencapai $50 \mathrm{~kg}$ buah ubi mentah per bulannya dengan harga per bungkus Rp. 5.000,00. Kelebihan produk dengan harga yang lebih murah dan kelemahan produk dengan kemasan yang masih sedarhana membuat sulitnya pemasaran/pendistribusian hasil olahan tersebut. Namun, walaupun pelaku usaha kecil di Desa Tanah Merah ini memiliki berbagai kekurangan dan keterbatasan, di sisi lain mereka memiliki kemauan keras untuk memajukan usaha yang sedang dijalankannya. Modal moril yang dimiliki adalah :

1. Rata-rata memiliki minat dan keahlian sesuai dengan usahanya

2. Memiliki motivasi yang tinggi untuk meningkatkan usahanya

3. Keyakinan bahwa usahanya dapat menopang ekonomi keluarga

Berdasarkan hal tersebut, program pengabdian kepada masyarakat ini dirancang untuk membantu menyelesaikan permasalahan yang dihadapi sehingga aktivitas usaha yang dikembangkan oleh Kelompok Mekar Indah dapat berjalan dengan baik. Bantuan program lebih diorientasikan pada aspek pemasaran dengan pendekatan pendampingan (mentoring) dari segi perencanaan pemasaran, desain pemasaran dan kemasan, distribusi pemasaran dan komunikasi untuk promosi pemasaran.

\section{METODE PELAKSANAAN}

Berdasarkan dengan permasalahan yang ada di UPPKS Mekar Indah dan tujuan dari pelaksanaan kegiatan pembinaan ini, maka model pelaksanaan kegiatan adalah dengan memberikan pelatihan atau workshop membangun/manajemen usaha, pelatihan pembukuan sederhana dan pendampingan dalam mengembangkan desain pemasaran serta simulasi penggunaan alat pengemasan produk.

\section{HASIL DAN PEMBAHASAN}

Adapun proses pada pelaksanaan kegiatan pendampingan UPPKS Mekar Indah sebagai berikut:

1. Pendidikan dan Pelatihan Desain Produk dan Kemasan

Kegiatan pendidikan dan pelatihan ini dilakukan pada tanggal 25 Agustus 2015. Adapun proses kegiatannya, yaitu: 
a) Pemberian materi tentang mendesain kemasan produk olahan keripik yang tepat, bagus dan terlihat menarik dengan metode ceramah, tanya jawab dan praktik mendesain produk.

b) Pemberian alat pengemasan (bag sealer)

c) Praktik penggunaan alat pengemasan (bag selaer) sesuai dengan prosedur pengoperasian alat tersebut.

Pada tahap ini diharapkan kelompok UPPKS mampu mendesain produk olahan semenarik mungkin hingga mampu meningkatkan minat konsumen untuk mengkonsumsinya.

2. Pendidikan dan Pelatihan Manajemen Usaha dan Business Plan

Kegiatan pendidikan dan pelatihan ini dilakukan pada tanggal 31 Agustus 2015. Sebelum pada proses pelatihan manajemen usaha dan business plan terlebih dahulu dilakukan evaluasi terhadap kegiatannnya sebelumnya. Hasilnya menunjukkan ada perkembangan yang baik dalam proses mendesain dan pengemasan produk olahan. Kemudian dilakukan pelatihan selanjutnya. Adapun proses kegiatannya, yaitu:

a) Pemberian materi tentang pengelolaan Usaha Kecil dan Menengah secara sederhana mulai dari kepengurusan kelompok UPPKS atau pengelolaan sumber daya manusia, pengelolaan produksi tentang bagaimana menentukan biaya pokok produksi dan strategi pemasaran. Pada tahap ini proses penyampaian dengan metode ceramah dan tanya jawab langsung antara pemateri dan peserta tentang proses manajemen usaha yang sudah dilakukan sehingga dapat dilakukan pembenahan tentang pengelolaan UPPKS Mekar Indah.

b) Pemberian materi tentang business plan. Tahap ini hampir sama dengan tahap sebelumnya hanya saja anggota kelompok UPPKS tersebut diberikan tugas untuk membuat business plan dan diberikan pendampingan.

3. Pelatihan Penyusunan Laporan Keuangan Kegiatan pelatihan ini dilakukan pada tanggal 07 September 2015. Sebelum memasuki pelatihan terlebih dahulu dilakukan evaluasi tentang pembuatan business plan. Pada tahap ini masih ditemukan pembenahan dalam pembuatan business plan. Kemudian dilanjutkan pelatihan penyusunan laporan keuangan. Adapun proses kegiatan yang dilakukan, yaitu:

a) Pemberian materi tentang pembukuan dan pembuatan laporan keuangan secara sederhana dengan metode ceramah, tanya jawab dan praktik.

b) Praktik pembukuan dan laporan keuangan dengan berdasarkan transaksi yang terjadi di kegiatan UPPKS Mekar Indah. c) Pemberian tugas kepada anggota kelompok tentang bagaimana cara membuat pembukuan dan laporan keuangan sesuai operasional UPPKS Mekar Indah. Dengan tugas ini diharapkan pertemuan minggu selanjutnya dapat dilakukan evaluasi atas perkembangan sistem pembukuan dan laporan keuangan UPPKS Mekar Indah.

4. Pelatihan Penyusunan Proposal Kredit

Kegiatan pelatihan ini dilakukan pada tanggal 14 September 2015. Dikarenakan pada tahap ini berkaitan langsung dengan kegiatan pelatihan sebelum tentang pengelolaan manajemen usaha, pembuatan business plan dan laporan keuangan, maka terlebih dahulu dilakukan evaluasi atas pelatihan sebelumnya sehingga pada pelatihan ini dapat dilaksanakan dengan mudah. Selanjutnya dilakukan pelatihan penyusunan proposal kredit. Adapun proses yang dilakukan pada tahap ini adalah pemberian materi tentang penyusunan proposal kredit mulai dari sistematika penyusunan dan apa yang harus dibuat dalam penyusunan proposal kredit. Metode yang dilakukan adalah ceramah, tanya jawab dan praktik penyusunan proposal.

Semua proses kegiatan tersebut dapat berjalan dengan baik walaupun ada kendala dalam proses pemahaman materi anggota kelompok UPPKS Mekar Indah sehingga penyelesaian tidak bisa begitu cepat.

Berdasarkan model pelaksanaan kegiatan pendampingan UPPKS Mekar Indah melalui pemberian pelatihan atau workshop dan pendampingan, maka kegiatan dapat terlaksana sesuai dengan yang direncanakan, yaitu:

1. Kelompok UPPKS Mekar Indah memiliki alat pengemasan produk olahan.

2. Kemasan produk lebih bagus dari yang sebelumnya.

3. Kelompok usaha mampu membuat pembukuan dan laporan keuangan.

4. Kelompok UPPKS mampu membuat rancangan bisnis.

5. Memiliki strategi dalam memasarkan produk.

Semua itu dapat dilakukan secara keseluruhan akan tetapi dikarenakan pengaruh tingkat pendidikan dan pengalaman anggota kelompok UPPKS Mekar Indah sehingga proses pencapaian kegiatan tersebut tidak begitu cepat, dibutuhkan kesabaran dalam melakukan pendampingan pada UPPKS Mekar Indah.

\section{KESIMPULAN}

Dengan berjalannya program pengabdian kepada masyarakat ini, maka kelompok UPPKS Mekar Indah merasakan beberapa manfaat yang diterima, yaitu: Kelompok UPPKS Mekar Indah memiliki alat pengemasan produk (bag sealer), kemasan produk lebih menarik, mampu membuat 
pembukuan atau laporan keuangan, dan memiliki strategi dalam memasarkan produk.

Berdasarkan evaluasi kegiatan pendampingan UPPKS Mekar Indah yang sudah dilakukan di Desa Tanah Merah Kabupaten Serdang Bedagai, maka rekomendasi yang bisa disampaikan pada laporan ini, yaitu:

1. Perlu ada keberlanjutan pendampingan dari pihak BKKBN terhadap UPPKS Mekar Indah. Pendampingan ini dilakukan agar keberlanjutan dari apa yang sudah diberikan kepada kelompok UPPKS Mekar Indah tetap dapat dijalankan sehingga dapat meningkatkan kesejahteraan atau pendapatan rumah tangga.

2. Perlu pendampingan kembali sesuai skema keberlanjutan kegiatan di atas. Kegiatan yang akan datang sesuai dengan skema, diharapkan kelompok UPPKS mampu mengembangkan usaha dengan melakukan peminjaman/kredit usaha serta penyebarluasan pangsa pasar. 